\title{
Survival, growth and carbon content in a forest plantation established after a clear-cutting in Durango, Mexico
}

\author{
Jesús Alejandro Soto-Cervantes ${ }^{1}$, Artemio Carrillo-Parra ${ }^{2}$, Rodrigo Rodríguez-Laguna ${ }^{3}$, José Javier Corral-Rivas ${ }^{4}$, \\ Marín Pompa-García ${ }^{4}$, Pedro Antonio Dominguez-Calleros ${ }^{\text {Corresp. } 4}$ \\ 1 Programa Institucional de Doctorado en Ciencias Agropecuarias y Forestales, Universidad Juárez del Estado de Durango, Durango, Mexico \\ 2 Instituto de Silvicultura e Industria de la Madera, Universidad Juárez del Estado de Durango, Durango, Mexico \\ 3 Instituto de Ciencias Agropecuarias, Universidad Autónoma del Estado de Hidalgo, Tulancingo, Hidalgo, Mexico \\ 4 Facultad de Ciencias Forestales, Universidad Juárez del Estado de Durango, Durango, México \\ Corresponding Author: Pedro Antonio Dominguez-Calleros \\ Email address: pdomingc@hotmail.com
}

Background. Forest plantations play an important role in carbon sequestration, helping to mitigate climate change. In this study, survival, biomass, growth rings and annual carbon content storage were evaluated in a mixed Pinus durangensis and $P$. cooperi plantation that was established after a clear-cutting. The plantation is eight years old and covers an area of 21.40 ha. Methods. Sixteen sites of $100 \mathrm{~m}^{2}$ were distributed randomly. At each site, two trees distributed proportionally to the diametric categories were destructively sampled (one per tree species). Two cross-sections were cut from each tree: The first at the base of the stump and the second at $1.30 \mathrm{~m}$. The width of tree rings of the first crosssection was measured using a stereoscopic microscope with precision in microns $(\mu \mathrm{m})$. The year-by-year basal diameter of each tree was recorded and biomass and carbon content was estimated using allometric equations. Results. The estimated survival was $75.2 \%$. The results of the ANOVA showed significant differences between the year-by-year width records of tree rings, the highest value corresponding to the fifth year. The average carbon sequestration per year is $0.30 \mathrm{~kg}$ for both studied tree species. Conclusions. $P$. durangensis and $P$. cooperi plantations adapt and develop well in Durango forests when they are established in areas that are subjected to clear-cutting. 
1 Survival, growth and carbon content in a forest plantation 2 established after a clear-cutting in Durango, Mexico

3

4

Jesús Alejandro Soto-Cervantes ${ }^{1}$, Artemio Carrillo Parra ${ }^{2}$, Rodrigo Rodríguez Laguna ${ }^{3}$, José Javier Corral-Rivas ${ }^{4}$, Marín Pompa-García ${ }^{4}$, Pedro Antonio Domínguez Calleros ${ }^{4}$

${ }^{1}$ Programa Institucional de Doctorado en Ciencias Agropecuarias y Forestales, Universidad Juárez del Estado de Durango, Durango, México

${ }^{2}$ Instituto de Silvicultura e Industria de la Madera, Universidad Juárez del Estado de Durango, Durango, México

${ }^{3}$ Instituto de Ciencias Agropecuarias, Universidad Autónoma del Estado de Hidalgo, Tulancingo, Hidalgo, México.

${ }^{4}$ Facultad de Ciencias Forestales, Universidad Juárez del Estado de Durango, Durango, México

Corresponding Author:

Pedro Antonio Domínguez Calleros

Río Papaloapan y Blvd. Durango S/N Col. Valle del Sur, Durango, Durango, 34000, México Email address: pdomingc@hotmail.com

\section{Abstract}

Background. Forest plantations play an important role in carbon sequestration, helping to mitigate climate change. In this study, survival, biomass, growth rings and annual carbon content storage were evaluated in a mixed Pinus durangensis and P. cooperi plantation that was established after a clear-cutting. The plantation is eight years old and covers an area of 21.40 ha. Methods. Sixteen sites of $100 \mathrm{~m}^{2}$ were distributed randomly. At each site, two trees distributed proportionally to the diametric categories were destructively sampled (one per tree species). Two cross-sections were cut from each tree: The first at the base of the stump and the second at 1.30 $\mathrm{m}$. The width of tree rings of the first cross-section was measured using a stereoscopic microscope with precision in microns $(\mu \mathrm{m})$. The year-by-year basal diameter of each tree was recorded and biomass and carbon content was estimated using allometric equations.

Results. The estimated survival was $75.2 \%$. The results of the ANOVA showed significant differences between the year-by-year width records of tree rings, the highest value corresponding to the fifth year. The average carbon sequestration per year is $0.30 \mathrm{~kg}$ for both studied tree species.

Conclusions. $P$. durangensis and $P$. cooperi plantations adapt and develop well in Durango forests when they are established in areas that are subjected to clear-cutting.

Key words: Growth rings, biomass, basal diameter. 
40

41

42

43

44

45

46

47

48

49

50

51

52

53

54

55

56

57

58

59

60

61

62

63

64

65

66

67

68

69

70

71

72

73

74

75

76

77

78

79

80

81

82

83

84

\section{Introduction}

In addition to the multiple benefits that forest ecosystems provide to society, forests can capture significant amounts of greenhouse gases (GHG), particularly carbon dioxide (Benjamín \& Masera, 2001; Aguirre-Calderón \& Jiménez-Pérez, 2011; Martínez et al., 2016; GonzálezCásares et al., 2019). However, the vegetation cover is not always adequate due to inappropriate forest management, and so the establishment of trees is necessary. Whatever the purpose of this action, reforestation (forest plantations) is an excellent alternative to mitigate high atmospheric concentrations of $\mathrm{CO}_{2}$ and, at the same time, reducing global warming (van Minnen et al., 2008; López-Reyes et al., 2016; Patiño et al., 2018; Ramírez-López \& Chagna-Avila, 2019). Proper soil management also contributes significantly to the expansion of the carbon sink in the terrestrial biosphere (Zambrano, Franquis \& Infante, 2004; Caviglia, Wingeyer \& Novelli, 2016; Halifa-Marin et al., 2019).

The Mexican forests have been considered as diverse in terms of tree species (Medrano et al., 2017) and have great potential as a carbon sink, and therefore are considered essential to assess carbon content in programs designed to mitigate global warming (Pompa-García \& SígalaRodríguez, 2017; Domínguez-Calleros et al., 2017). Frequently 50\% carbon concentration of total biomass has been assumed, however, this statement leads to inaccurate carbon estimates, due to variation of the carbon concentration between arboreal components and tree species (Pompa-García \& Yerena-Yamalliel, 2014; Wang et al., 2015; Hernández-Vera et al., 2017). Forest plantations of one or two species stand out as the most efficient way to increase carbon sequestration capacity of forest regions, because forest owners plant normally fast-growing tree species (Reyes, León \& Herrero, 2019).

Pinus durangensis and $P$. cooperi are species frequently used in forest reforestations in the state of Durango (Prieto et al., 2016). However, successful forest plantation requires planting quality seedlings with optimal growth potential. Thus, foresters need to use seedlings with plant attributes (i.e. shoot height, stem diameter, root mass, shoot to root ratio, drought resistance, mineral nutrient status) that favor the best chance of successful establishment once they are field planted (Grossnickle, 2012; Pérez-Luna et al., 2019, 2020). The use of quality seedlings favors success in plantations under climate change conditions (Vallejo et al., 2012). In Mexico 57\% of mortality is caused by the poor quality of the plant (Prieto et al., 2016), also another important factor are the deficiencies that occur during the planting process (Burney et al., 2015), for example, if the strain becomes too deep the plant will suffocate and if the strain becomes shallow, the roots could be left on the surface and the plant will dehydrate, in addition, covering the stem with too much soil reduces the vigor of the plant and makes difficult its access to water (CONAFOR, 2010).

For the proper management of forests in Mexico, including areas planted with the main commercial tree species, different silvicultural systems are employed in order to ensure the regeneration of the site: The Mexican Irregular Forest Management Method (MMOBI) and the Silvicultural Development Method (MDS) (Solís et al., 2006; Pérez-Verdín et al., 2009; PérezRodriguez et al., 2013). The former is used in forest stands with a high tree species richness, and the latter in stands dominated by one or two tree species of pine (Hernández-Díaz et al., 2008). Moreover, in areas covered with little or no slope, the use of a clear-cutting as a regeneration method can be also used. It is characterized by having periodic crops, determined by commercial rotations (Gadow, Sánchez \& Aguirre, 2004), and their regeneration can be natural or artificial. If the regeneration is artificial, then the use of fast-growing species is preferable. 
85

86

87

88

89

90

91

92

93

94

95

96

97

98

99

100

101

102

103

104

105

106

107

108

109

110

111

112

113

114

115

116

117

118

119

120

121

122

123

124

125

126

127

128

129

130

Although clear-cutting can be used successfully in Mexican forests, this silvicultural method is still considered inappropriate, because complete tree removal of an area may cause degradation of forest components such as soil, water quality, fauna, etc., at least at the beginning of the forestry process (Keenan \& Kimmins, 1993; Hernández, Jaeger \& Samperio, 2017; MonárrezGonzález et al., 2018). However, its use has economic advantages. On the one hand, an intermediate economic income is possible, through silvicultural interventions (thinnings); on the other, the reduction of competition improves the dimensions of the trees that remain standing and the $\mathrm{CO}_{2}$ sequestration increases (Rodríguez-Larramendi et al., 2016; Rodríguez-Ortiz et al., 2019). Investigations that address the survival behavior and the carbon content of mixed Pinus cooperi and $P$. durangensis plantations in the initial phase are scarce (Návar et al., 2004). The study of these aspects is important for the proper management and conservation of forest plantations in Mexico. As a hypothesis of this study, we consider that plantations of Pinus cooperi and $P$. durangensis established after clear-cuttings, show high levels of survival and growth, and contribute efficiently to carbon sequestration. Thus, the objectives of this work were to evaluate survival, the width of tree rings and carbon content in a plantation of Pinus durangensis and P. cooperi at a site exposed to clear-cutting in the State of Durango, Mexico.

\section{Materials \& Methods}

Study area

This study was conducted in the private property "Las Veredas", municipality of San Dimas, Durango, Mexico, belonging to the Compañía Silvícola Chapultepec, S. DE R. L. DE C. V., in the coordinates of the site are: $24^{\circ} 20^{\prime} 40^{\prime \prime} \mathrm{N}$ and $105^{\circ} 51^{\prime} 20^{\prime \prime} \mathrm{W}$ (Fig. 1). The climate is temperate with a brief rainy season during the summer months $\left(\mathrm{C}_{\mathrm{W}}\right)$, and the temperature ranges between -3 and $18{ }^{\circ} \mathrm{C}$ (Garcia, 2004). The topography is characterized by hills, with slopes ranging from soft to medium ( 0 to $50 \%$ ). The area occupied by the clear-cutting has a slope of $9 \%$ and an altitude of $2803 \mathrm{~m}$ asl. The average annual rainfall recorded during the period 2010 to 2018 was $1,034.5 \mathrm{~mm}$ (this value was recorded by the weather station in the town of Vencedores, located $15 \mathrm{~km}$ away from the study area). Rainfall occurs in the months of June, July, August and September; The first frost occurs in October and the last frost occurs in June; snowfall occurs most frequently in the months of December and January (FSC \& SmartWood, 2002). The vegetation is characterized by mixed coniferous and broadleaved forests. The dominant pine species are: Pinus durangensis Martínez, P. cooperi Blanco, P. teocote Schl. and P. strobiformis Engelm. The main oak species are: Quercus rugosa Née and Q. sideroxyla Bonpl, in addition some species of the genera Juniperus, Arbutus, and Alnus are also part of the forest composition (González-Elizondo et al., 2012).

\section{Figure 1}

\section{Forestry background}

Before the clear-cutting, the stand had a stocking of $220.4 \mathrm{~m}^{3} \mathrm{ha}^{-1}$ of trees of the following genera: Pinus, Quercus, Juniperus and Arbutus (PMF, 2010). The trees were harvested at the beginning of 2010 on an area of 21.40 ha. Months later, during the rainy season, the plantation was established with seedlings of $P$. durangensis and $P$. cooperi (it was not possible to know the proportion, but $P$. durangensis was planted in greater quantity). The plantation was produced with germplasm collected from trees growing in natural stands next to the study area. Land preparation consisted of clearing, scattering and applying the controlled burning of forest waste. To improve soil conditions, the ground was plowed using a D-6 track-type tractor, equipped with 
131 a ripper, breaking equidistant lines $(2 \mathrm{~m})$ at a depth of $60 \mathrm{~cm}$, in the perpendicular direction to

132

133

134

135

136

137

138

139

140

141

142

143

144

145

146

147

148

149

150

151

152

153

154

155

156

157

158

159

160

161

162

163

164

165

166

167

168

169

170

171

172

173

174

175

the slope. The seedlings were 12 months old with a height of between 15 and $20 \mathrm{~cm}$ and a diameter at the base of the stem of $5 \mathrm{~mm}$. They were planted using the common strain method in a "real frame" at a spacing of $2 \times 2 \mathrm{~m}$ to generate a density of 2,500 seedlings ha ${ }^{-1}$.

\section{Field Evaluation}

Sixteen (16) circular sites of $100 \mathrm{~m}^{2}$ were established, distributed completely randomly to evaluate survival according to the recommendations of CONAFOR (2013). In addition to survival, variables such as diameter $(\mathrm{cm})$ and height $(\mathrm{m})$, were measured using a Vernier and hypsometer $\left(\right.$ Vertex $\left.\mathrm{V}^{\circledR}\right)$, respectively. The sample implied the demolition of 32 trees, distributed proportionally to the diametric categories (16 of each tree species). Two cross-sections were obtained from each tree (over-bark and under-bark): one was cut at the base of the tree and the second one at $1.3 \mathrm{~m}$ above ground.

The cross-sections were labeled, dried and polished, and the measurement of each growth ring was subsequently performed using a stereomicroscope with precision in $\mu \mathrm{m}$. This process was carried out in the dendroecology laboratory at the Facultad de Ciencias Forestales of the Universidad Juárez del Estado de Durango. The year-by-year width of each tree ring was estimated by the average of four-way measurements. The measurements were performed by starting from the year 2017, looking back to previous years.

\section{Estimation of biomass and carbon content.}

In order to obtain the total aerial biomass, the equation developed by Návar et al. (2004) was used for the species in question, which takes the basal diameter as a predictive variable (Equation $1)$.

$$
y_{i}=a(D B)^{b}
$$

\section{Where}

$y_{i}=$ Total aerial biomass

$a=0.0199$ y $b=2.5488$

$D B=$ Basal tree diameter $(\mathrm{cm})$

The carbon content for Pinus cooperi was calculated according to the percentage reported by Pompa-Garcia et al. (2017), who indicate that, the carbon concentration for this species is $49.64 \%$ of the total aerial biomass. For Pinus durangensis the carbon concentration reported for Hernández-Vera et al. (2017) was used (50.36\% of the total aerial biomass).

Considering that the terrain is relatively flat and homogeneous, an analysis of variance (ANOVA) was performed under a completely randomized experimental design for the statistical analysis of the data. The classification variables were the two studied tree species and the tree age. The response variables were the year-by-year width of the tree ring, the biomass and the carbon content. The Shapiro-Wilk Normality Test was used to evaluate data normality and equality of variances for all response variables. Significant differences $(p \leq 0.05)$ for the year-byyear width of the tree rings were evaluated with the Tukey Means Comparison Test, while the Kruskal-Wallis Non-Parametric Test was used to evaluate significant differences among the median values of biomass and carbon content because these two variables did not meet the normality data assumption. These analyzes were performed using $\mathrm{R}^{\circledR}$ statistical software ( $R$ Core Team, 2019). 
176 Results

177 Table 1 shows the descriptive statistics of the sampled trees. Similarity is observed in the

178 parameters evaluated (diameter at the base and total height), which means that, at the age of eight years, the studied tree species show similar growth patterns.

180

181

182

183

184

185

186

187

188

189

190

191

192

193

194

195

196

197

198

199

200

201

202

203

204

205

206

207

208

209

210

211

212

213

214

215

216

217

218

219

220

221

\section{Table 1.}

Eight years after the establishment of the plantation, an average survival of $75.2 \%$ was observed for the two species, which corresponds to a density of 1,881 trees per ha (Table 2). From studied sites stand out 10 and 2 which showed the highest and lowest survival rates, respectively. No survival comparisons were made, because it was not possible to know the proportion in which both species were planted, however, Pinus durangensis was found to be planted in a greater quantity (almost double according to the observed average of the number of trees of the sampling sites), and assuming that survival had been the same for the two studied trees species, an initial density of 2,500 trees ha- ${ }^{-1}$ was planted $\left(25\right.$ trees in $\left.1000 \mathrm{~m}^{2}\right)$.

\section{Table 2.}

The analysis of variance indicated that there are highly significant statistical differences ( $p$ $<0.001)$ in the year-by-year width of the tree rings of the studied tree species. The Tukey test (Fig. 2), forms 6 groups for both tree species, among these, the values of the first and fifth year stand out, which were, respectively, the minor and major width rings. Starting from fifth year, the width of the tree rings shows a decline, and allows their values to be grouped with the values of the third and fourth years. Although the width of the tree rings was slightly larger in $P$. cooperi, no significant statistical differences $(p=0.9336)$ were found among the two studied tree species. The upper and lower horizontal lines crossing the vertical bars (standard deviation) indicate that the year-by-year width growth of the tree rings has been similar among the tree species until the period of time evaluated in this study.

\section{Figure 2.}

The Kruskal-Wallis Test indicated that there are significant differences in the estimates of yearby-year biomass and carbon content $(p \leq 0.05)$. The comparison of medians using the Bonferroni method does not show significant differences in those years whose observations were consecutive. In contrast, comparisons between discontinuous years showed significant differences $(p<0.01)$ (Table 3).

\section{Table 3.}

Estimates of year-by-year biomass and carbon content among tree species did not show significant statistical differences $(p \geq 0.05)$.

The accumulation of biomass showed higher values after the fifth year in the studied species, which is a product of the increase in the dimensions of the BD of the trees (Fig. 3).

Figure 3. 
222 Estimates of biomass and carbon content year-by-year of the studied species are shown in Table 223 4. It is observed that the accumulation of biomass and carbon content increases with increasing 224 age. However, Pinus cooperi shows a decrease in the seventh year with respect to the previous 225 year. Considering that a tree has in average an estimate of 4.42 and $2.21 \mathrm{~kg}$ of biomass and 226 carbon content, respectively, at the age of 7 years, the studied plantation accounts for 8,315.12

\section{Table 4.}

\section{Discussion}

The results of survival reported in this work $(75.2 \%)$ are superior than the findings reported by Prieto et al. (2016), who found out an average of $43 \%$ in a forest plantation studied in Durango State. These survival results are also superior to those showed by Bojórquez, Rodríguez \& Flores (2015) in 25-year-old plantations of $P$. durangensis, $P$. engelmannii, $P$. cooperi and $P$. arizonica var. in Durango State. Although different species were dealt with in a similar study, our results are also better than those reported by Vásquez-García et al. (2016), who informed an average survival of $69 \%$ in four-year old plantations of $P$. greggii Englem and P. oaxacana Mirov - in three communities in the High Oaxacan Mixtec region in Southern Mexico. However, our survival results were inferior than those reported by Prieto-Ruiz et al. (2007) in an 18-month Pinus cooperi plantation established on a site in the municipality of Durango, reaching a survival rate of $85.6 \%$. They are also inferior than those informed by Prieto-Ruiz et al. (2018), who reported a $93 \%$ of survival in a Pinus cooperi plantation after 13 months of its establishment at a site in Agua Zarca, Otinapa, Durango.

Prieto et al. (2018), argue that successful plantations and reforestations depend on the quality of the plant, as it is decisive for its adaptation and development after planting (Fontana, Pérez \& Luna, 2018). In our study, it is observed that both species show uniform growth from their establishment to the fifth year of planting. However, from the sixth year onwards, plant growth tends to decline, remaining low until the end of the study, being more noticeable in $P$. cooperi. Crecente-Campo et al. (2007) documented that the decrease in plant growth is influenced among other factor by the competition that trees experience from other trees, and that competition increases with increasing age of the plantation (Soto-Cervantes et al., 2016). Although this work does not include an analysis that correlates ecological factors with tree growth, studies performed by Anchukaitis et al. (2013), Gutiérrez-García \& Ricker (2019), documented that maximum temperature negatively influences radial growth of the trees. However, the growth, and consequently, the $\mathrm{CO}_{2}$ sequestration may vary with environmental conditions of the site and the tree species evaluated (Haghshenas et al., 2016; Pompa-Garcia \& Sigala-Rodriguez, 2017; Lanza, Chartier \& Marcora, 2018). These growth patterns can be attributed to the fact that, at the beginning of the plantation, the genotype-environment interaction and the plasticity of the species influence the adaptability of the plants to a specific sites (Miranda, 2006; Thomas et al., 2015).

The width of the tree rings is the most used parameter to evaluate the growth rate of the trees (Dobner, Huss \& Tomazello, 2018). In this study, the lowest width ring growth value was presented during the first year, this can be attributed to plant adaptation to transplant stress (e.g., drought, salinity, and temperature extremes) (Pérez-Luna et al., 2020). On the other hand, the tree development during the fifth year was higher and after that it showed some reduction in growth caused by tree competition (Crecente-Campo et al., 2007). The average width growth of 
268 the rings observed for both tree species was $11.51 \mathrm{~mm} \mathrm{yr}^{-1}$. Pompa-García et al. (2018), 269 evaluated the width growth rings in $P$. arizonica y $P$. cembroides Zucc in northern Mexico and 270 found that their average increase was $1.84 \mathrm{~mm} \mathrm{yr}^{-1}$ and $1.73 \mathrm{~mm} \mathrm{yr}^{-1}$, respectively.

271 A study in Pinus taeda L. developed by Dobner, Huss \& Tomazello (2018), found out that the 272 width growth of tree rings varied between 6 to $9 \mathrm{~mm}$ during the first three to six years before 273 performing silvicultural activities. On the other hand, Melandri, Dezzeo \& Espinoza de Pernía 274 (2007) in a study with Pinus caribaea var. hondurensis in Venezuela indicated that the width 275 growth of tree rings is dependent on various site factors, as well as atmospheric, in this case they 276 pointed out that different rainfall regimes yielded significantly differences in with growth rings. Several studies related the radial growth rate and the characteristics of the rings with environmental variables such as temperature, precipitation and light intensity (García-Suárez, Butler \& Baillie, 2009; Chacón-de la Cruz \& Pompa-García, 2015). However, due to the dynamics of the exchange activity during the formation of the wood, the relationship of growth with climatic conditions is very complex and inconstant (Żywiec et al., 2017).

Studies indicate that tree spacing influences total tree volume, width growth of rings, and length and diameter of branches (Hart, 2010). Also, with increasing thinning intensity the effect on the thickness of the width of tree rings is greater (Zhang et al., 2006). Baldwin et al. (2000), studied the effects of spacing and thinning on stand and tree characteristics of a 38-year-old Pinus taeda L plantation and found out that, at higher initial spacing, trees develop greater diameter and crown length. This favors the formation of wider tree rings and more early wood (Rossi, Morin \& Deslauriers, 2012). Rodríguez-Ortiz (2010), recommended an initial spacing of 2.40 to $2.75 \mathrm{~m}$ for Pinus patula Schl, because it is a tree species sensitive to competition during its first years of development.

In this study, estimates of year-by-year biomass and carbon content were analyzed for individual trees, however, estimates per hectare were not performed because survival in previous years was unknown and results extrapolation based on survival at the time of assessment could be considered erroneous. In this study the average carbon content per tree was estimated in $0.30 \mathrm{~kg}$ $\mathrm{yr}^{-1}$ for both studied tree species. Pompa-García et al. (2018) estimated that adult trees of Pinus arizonica and $P$. cembroides accumulate $4.80 \mathrm{~kg} \mathrm{C} \mathrm{yr}^{-1}$ and $4.84 \mathrm{~kg} \mathrm{C} \mathrm{yr}^{-1}$, respectively. Pacheco et al. (2007) evaluated the accumulated biomass content in a six-year-old Pinus greggii plantation, and found out that the average aerial dry biomass was $8.0 \mathrm{~kg}$ per tree. These results are above those observed in this study with an average per tree of $4.39 \mathrm{~kg}$ for Pinus durangensis and $4.46 \mathrm{~kg}$ for $P$. cooperi.

Intensive forestry is key to maintaining or increasing stand productivity in the future, wood biomass from plantations of fast-growing trees is an alternative because it is produced in short periods of time (Thiers, Gerdinga \& Schlatter, 2007). However, intensive forest management may impact the conservation of plant diversity and the regulation of water flows (MonárrezGonzález et al., 2018). The results of this research suggest that clear-cuttings are suitable logging practices for the studied tree species in the study area, especially because they create optimal growing conditions for pine trees. However, after opening the gaps it is recommended to replant the area with certain additional complementary practices to protect and guarantee its good development (e.g. fencing, firebreaks, pest prevention, etc.), and avoid risk of soil erosion and loss of biodiversity. The estimates of carbon content made in this study coincide with the results reported by Pacheco et al. (2007), in the sense that young plantations have high growth rates and therefore they also have a greater potential for carbon sequestration. 


\section{Conclusions}

315 According to the results of the present study, the observed survival percentage $(75.2 \%)$ is

316 considered high in comparison with other similar studies. It indicates that both Pinus

317 durangensis and P. cooperi adapt and develop well in areas harvested with clear-cutting in the

318 forests of Durango. The width growth of the tree rings was similar in the two species but

319 different among the years evaluated. No significant differences were found in terms of biomass

320 and carbon content among the studied tree species. The accumulation of biomass and carbon

321 content observed in the studied forest plantation is considered to be high, accounting for

$3228,315.12$ and $4,157.56 \mathrm{~kg} \mathrm{ha}^{-1}$, respectively, at the age of 7 years. The study reveals that clear-

323 cuttings can be successfully used as logging practices in the study area to create even aged pine

324 stands and increase the productivity of these forests in terms of timber and $\mathrm{CO}_{2}$ sequestration,

325 among other ecosystems services.

326

327

328

329

330

331

332

333

334

335

336

337

338

339

340

341

342

343

344

345

346

\section{Acknowledgements}

To CONACYT for the financial support provided to the first author who carried out his training in the Programa Institucional de Doctorado en Ciencias Agropecuarias y Forestales (PIDCAFUJED). Our thanks to C.P. Alfonso Gerardo Fernández de Castro Toulet, legal representative of the Compañía Silvícola Chapultepec S. DE R.L. de C.V., for providing access to the study area for data collection. To UCODEFO No. 4 (Unidad de Conservación y Desarrollo Forestal No. 4 La Victoria Miravalles SC), for providing information related to the study area.

\section{References}

Aguirre-Calderón ÓA, Jiménez-Pérez J. 2011. Evaluación del contenido de carbono en bosques del sur de Nuevo León. Revista Mexicana de Ciencias Forestales 2:73-84 DOI: 10.29298/rmcf.v2i6.575.

Anchukaitis KJ, Taylor MJ, Martin-Fernandez J, Pons D, Dell M, Chopp C, Castellanos EJ. 2013. Cronología anual y respuesta climática en Abies guatemalensis Rehder (Pinaceae) en Centroamérica. The Holocene 23:270-277 DOI: 10.1177/0959683612455548.

Baldwin VC, Peterson KD, Clark III A, Ferguson RB, Strub MR, Bower DR. 2000. The effects of spacing and thinning on stand and tree characteristics of 38-year-old loblolly pine. Forest Ecology and Management 137: 91-102 DOI: 10.1016/S0378-1127(99)00340-0.

Benjamín JA, Masera O. 2001. Captura de carbono ante el cambio climático. Madera y Bosques 7:3-12.

Bojórquez MM, Rodríguez LG, Flores JM. 2015. Evaluación de plantaciones de cuatro especies forestales en el estado de Durango. Ciencia y Tecnología Universitaria (Versión imprimible). Available at http://reaxion.utleon.edu.mx/Art Impr Evaluacion plantaciones cuatro especies forestale s Durango.html.

Burney O, Aldrete A, Alvarez R, Prieto JA, Sánchez JR, Mexal JG. 2015. México—Addressing challenges to reforestation. Journal of Forestry 113:404-413 DOI: 10.5849/jof.14-007.

Caviglia OP, Wingeyer AB, Novelli LE. 2016. El rol de los suelos agrícolas frente al cambio climático. Serie de Extensión INTA Paraná 78:27-32.

Chacón-de la Cruz JE, Pompa-García M. 2015. Response of tree radial growth to evaporation, as indicated by earlywood and latewood. Revista Chapingo Serie Ciencias Forestales y del Ambiente 21: 57-65 DOI: 10.5154/r.rchscfa.2014.10.050.

Comisión nacional forestal (CONAFOR). 2013. Metodología para realizar y presentar los

Peer] reviewing PDF | (2020:02:45821:2:0:NEW 11 Jun 2020) 
360

361

362

363

364

365

366

367

368

369

370

371

372

373

374

375

376

377

378

379

380

381

382

383

384

385

386

387

388

389

390

391

392

393

394

395

396

397

398

399

400

401

402

403

404

405

informes de sobrevivencia inicial (ISI) de las plantaciones forestales comerciales (aspectos técnicos): 21 p. Available at www.conafor.gob.mx/apoyos/index.php/inicio/download/1422.

Comisión nacional forestal (CONAFOR). 2010. Prácticas de reforestación. Manual básico. Primera edición, 66 p. Available at https://www.conafor.gob.mx/BIBLIOTECA/MANUAL_PRACTICAS_DE_REFORESTACIO N.PDF.

Crecente-Campo F, Amigo-López F, Álvarez-González J, Diéguez-Aranda U. 2007. Elaboración de un modelo de perfil de copa para Pinus radiata D. Don en Galicia. Cuadernos de la Sociedad Española de Ciencias Forestales 23:159-165.

Dobner M, Huss J. Tomazello M. 2018. Wood density of loblolly pine trees as affected by crown thinnings and harvest age in southern Brazil. Wood Science and Technology 52: 465-485 DOI: $10.1007 / \mathrm{s} 00226-017-0983-9$.

Domínguez-Calleros PA, Rodríguez-Laguna R, Capulín-Grande J, Razo-Zárate R, Díaz-Vásquez MA. 2017. Influencia de factores edáficos en el crecimiento de una plantación de Pinus greggii Engelm. en Santiago de Anaya, Hidalgo, México. Madera y Bosques 23:145-154 DOI: $10.21829 / \mathrm{myb} .2017 .2321522$.

Fontana M, Pérez V, Luna C. 2018. Efecto del origen geográfico en la calidad morfológica de plantas de Prosopis alba (Fabaceae). Revista de Biología Tropical 66:593-604 DOI: 10.15517/rbt.v66i2.33383.

FSC (Forest Stewardship Council), SmartWood. 2002. Resumen Público de Certificación de Compañía Silvícola Chapultepec S. de R.L. de C.V. 40 p. Available at https://docplayer.es/72124326-Resumen-publicode-certificacion-compania-silvicolachapultepec-s-de-r-l-de-cv.html\#show full text.

Gadow Kv, Sanchez OS, Aguirre ÓA. 2004. Manejo forestal con bases científicas. Madera y Bosques 10:3-16 DOI: 10.21829/myb.2004.1021271.

García ME. 2004. Modificaciones al sistema de clasificación climática de Köppen, 6 ed. Instituto de Geografia: Universidad Nacional Autónoma de México, México: Serie Libros, 98 p.

García-Suárez AM, Butler CJ, Baillie GL. 2009. Climate signal in tree-ring chronologies in a temperate climate: A multi-species approach. Dendrochronologia 27: 183-198 DOI: 10.1016/j.dendro.2009.05.003.

González-Cásares M, Pompa-García M, Venegas-González A, Domínguez-Calleros P, Hernández-Díaz J, Carrillo-Parra A, González-Tagle M. 2019. Hydroclimatic variations reveal differences in carbon capture in two sympatric conifers in northern Mexico. PeerJ 7: e7085 DOI: $10.7717 /$ peerj.7085.

González-Elizondo MS, González-Elizondo M, Tena-Flores JA, Ruacho-González L, LópezEnríquez IL. 2012. Vegetación de la Sierra Madre Occidental, México: Una síntesis. Acta Botanica Mexicana 100:351-404 DOI: 10.21829/abm100.2012.40.

Grossnickle SC. 2012. Why seedlings survive: influence of plant attributes. New Forests 43:711738 DOI: $10.1007 / \mathrm{s} 11056-012-9336-6$.

Gutiérrez-García G, Ricker M. 2019. Influencia del clima en el crecimiento radial en cuatro especies de coníferas en la sierra de San Antonio Peña Nevada (Nuevo León, México). Revista Mexicana de Biodiversidad 90:1-14 DOI: 10.22201/ib.20078706e.2019.90.2676.

Haghshenas M, Mohadjer MR, Attarod P, Pourtahmasi K, Feldhaus J, Sadeghi SM. 2016. Climate effect on tree-ring widths of Fagus orientalis in the Caspian forests, northern Iran. Forest Science and Technology 12:176-182 DOI: 10.1080/21580103.2016.1144542. Halifa-Marín A, Pérez-Cutillas P, Almagro M, Martínez-Mena M, Boix-Fayos C. 2019.

Peer] reviewing PDF | (2020:02:45821:2:0:NEW 11 Jun 2020) 
406

407

408

409

410

411

412

413

414

415

416

417

418

419

420

421

422

423

424

425

426

427

428

429

430

431

432

433

434

435

436

437

438

439

440

441

442

443

444

445

446

447

448

449

450

451

Dinámica geomorfológica fluvial y cambios de usos del suelo: impacto en los reservorios de carbono de suelos y sedimentos. Bosque (Valdivia) 40:3-16 DOI: 10.4067/s071792002019000100003.

Hart JF. 2010. A review of the effects of silviculture on wood quality. Forestry 75: 107-138 DOI: $10.14288 / 1.0103111$.

Hernández UF, Jaeger D, Samperio JI. 2017. Bioenergy potential and utilization costs for the supply of forest woody biomass for energetic use at a regional scale in Mexico. Energies 10: 1192 DOI: 10.3390/en10081192.

Hernández-Díaz JC, Corral-Rivas JJ, Quiñones-Chávez A, Bacon-Sobbe JR, Vargas-Larreta B. 2008. Evaluación del manejo forestal regular e irregular en bosques de la Sierra Madre Occidental. Madera Bosques 14:25-41.

Hernández-Vera D, Pompa-García M, Yerena-Yamallel JI, Alanís-Rodríguez E. 2017. Variación de la concentración de carbono en tres especies mexicanas de pino. Bosque (Valdivia) 38:381-386 DOI: 10.4067/S0717-92002017000200015.

Keenan RJ, Kimmins JP. 1993. The ecological effects of clear-cutting. Environmental Reviews 1:121-144 DOI: 10.3390/en10081192.

Lanza MG, Chartier MP, Marcora PI. 2018. Relación clima-crecimiento radial de Polylepis australis en un gradiente altitudinal en las Sierras Grandes de Córdoba, Argentina. Ecología Austral 28: 278-290.

López-Reyes LY, Domínguez-Domínguez M, Martínez-Zurimendi P, Zavala-Cruz J, GómezGuerrero A, Posada-Cruz S. 2016. Carbono almacenado en la biomasa aérea de plantaciones de hule (Hevea brasiliensis Müell. Arg.) de diferentes edades. Madera y Bosques 22:49-60 DOI: 10.21829/myb.2016.2231456.

Martínez RA, Aguirre ÓA, Vargas LB, Jiménez PJ, Treviño EJ, Yamallel JI. 2016. Modelación de biomasa y carbono arbóreo aéreo en bosques del estado de Durango. Revista Mexicana de Ciencias Forestales 7:91-105 DOI: 10.29298/rmcf.v7i35.77.

Medrano MdJ, Hernández FJ, Corral S, Nájera JA. 2017. Diversidad arbórea a diferentes niveles de altitud en la región de El Salto, Durango. Revista Mexicana de Ciencias Forestales 8:5768.

Melandri JL, Dezzeo N, Espinoza de Pernía N. 2007. Periodicidad de los anillos de crecimiento en Pinus caribaea var. hondurensis proveniente de una plantación del estado Mérida, Venezuela. Revista Forestal Venezolana 51: 57-66.

Miranda AR. 2006. Características genéticas de los materiales de reproducción. Influencia sobre la calidad de la planta. In Calidad de planta forestal para la restauración en ambientes mediterráneos, estado actual de conocimientos. Organismo Autónomo de Parques Nacionales. 47-66.

Monárrez-González JC, Pérez-Verdín G, López-González C, Márquez-Linares MA, González Elizondo MdS. 2018. Efecto del manejo forestal sobre algunos servicios ecosistémicos en los bosques templados de México. Madera y Bosques 24:e2421569 DOI: $10.21829 /$ myb.2018.2421569.

Návar JdJ, González N, Graciano JdJ, Dale V, Parresol B. 2004. Additive biomass equations for pine species of forest plantations of Durango, Mexico. Madera y Bosques 10:17-28 DOI: 10.21829/myb.2004.1021272.

Pacheco FC, Aldrete A, Gómez A, Fierros AM, Cetina VM, Vaquera H. 2007. Almacenamiento de carbono en la biomasa aérea de una plantación joven de Pinus greggii Engelm. Revista Fitotecnia Mexicana 30:251-254.

PeerJ reviewing PDF | (2020:02:45821:2:0:NEW 11 Jun 2020) 
452

453

454

455

456

457

458

459

460

461

462

463

464

465

466

467

468

469

470

471

472

473

474

475

476

477

478

479

480

481

482

483

484

485

486

487

488

489

490

491

492

493

494

495

496

497

Patiño S, Suárez LN, Andrade HJ, Segura MA. 2018. Captura de carbono en biomasa en plantaciones forestales y sistemas agroforestales en Armero-Guayabal, Tolima, Colombia. RIAA 9: DOI: 10.22490/21456453.2312.

Pérez-Luna A, Prieto-Ruíz JÁ, López-Upton J, Carrillo-Parra A, Wehenkel C, Chávez-Simental JA, Hernández-Díaz JC. 2019. Some factors involved in the success of side veneer grafting of Pinus engelmannii Carr. Forests 10:112 DOI: 10.3390/f10020112.

Pérez-Luna A, Wehenkel C, Prieto-Ruíz JÁ, López-Upton J, Hernández-Díaz JC. 2020. Survival of side grafts with scions from pure species Pinus engelmannii Carr. and the P. engelmannii $\times$ P. arizonica Engelm. var. arizonica hybrid. PeerJ 8:e8468 DOI: 10.7717/peerj.8468.

Pérez-Rodríguez F, Vargas-Larreta B, Aguirre-Calderón OA, Corral-Rivas JJ, Rojo-Alboreca A. 2013. Proceso analítico jerárquico para seleccionar métodos de manejo forestal en Durango. Revista Mexicana de Ciencias Forestales 4:55-72 DOI: 10.29298/rmcf.v4i15.448.

Pérez-Verdín G, Hernández-Díaz JC, Márquez-Linares MA, Tecle A. 2009. Aplicación de técnicas multicriterio en el manejo integral forestal en Durango, México. Madera y Bosques 15:27-46 DOI: 10.21829/myb.2009.1511195.

Pompa-García M, Sígala-Rodríguez JA, Jurado E, Flores J. 2017. Tissue carbon concentration of 175 Mexican forest species. iForest-Biogeosciences and Forestry 10: 754-758 DOI: 10.3832/ifor2421-010.

Pompa-García M, Sígala-Rodríguez JA. 2017. Variation of carbon uptake from forest species in Mexico: a review. Madera y Bosques 23: 225-235 DOI: 10.21829/myb.2017.2321512.

Pompa-García M, Venegas-GonzáLez A, Júnior, AA, Sigala-Rodríguez JA. 2018. Dendroecological approach to assessing carbon accumulation dynamics in two Pinus species from northern Mexico. Tree-Ring Research 74: 196-209 DOI: 10.3959/1536-109874.2.196.

Pompa-García M, Yerena-Yamalliel JI. 2014. Concentración de carbono en Pinus cembroides Zucc: fuente potencial de mitigación del calentamiento global. Revista Chapingo Serie Ciencias Forestales y del Ambiente 20:169-175 DOI: 10.5154/r.rchscfa.2014.04.014.

Prieto JA, Aldrete A, Sánchez JR, Hernández JC. 2016. Antecedentes sobre las reforestaciones en México. In Las reforestaciones en México, problemática y alternativas de solución. Prieto JA, Goche JR, eds. Universidad Juárez del Estado de Durango. Durango, México. 14-22.

Prieto JA, Domínguez-Calleros PA, Cornejo-Oviedo EH, Návar-Cháidez JDJ. 2007. Efecto del envase y del riego en vivero en el establecimiento de Pinus cooperi Blanco en dos condiciones de sitio. Madera y Bosques 13:79-97 DOI: 10.21829/myb.2007.1311237.

Prieto JA, Duarte SA, Goche JR, González MM, Pulgarín MA. 2018. Supervivencia y crecimiento de dos especies forestales, con base en la morfología inicial al plantarse. Revista Mexicana de Ciencias Forestales 9:151-168 DOI: 10.29298/rmcf.v9i47.182.

Programa de manejo forestal (PMF). 2010. P.P. Lotes números Cuatro, Cinco y Ocho fracciones Oriente del fraccionamiento del predio rústico "Las Veredas", municipio de San Dimas, Dgo. Unidad de Conservación y Desarrollo Forestal No. 4 "La Victoria-Miravalles", S. C. Durango, México.

R Core Team. 2019. R: A language and environment for statistical computing. R Foundation for Statistical Computing, Vienna, Austria. URL https://www.R-project.org/.

Ramírez-López JL, Chagna-Avila EJ. 2019. Secuestro de carbono en la biomasa aérea de una plantación de Eucalyptus grandis W. Hill. Revista Cubana de Ciencias Forestales 7:86-97. Reyes JL, León MA, Herrero G. 2019. Influencia de la fertilización mineral sobre la retención de 
498

499

500

501

502

503

504

505

506

507

508

509

510

511

512

513

514

515

516

517

518

519

520

521

522

523

524

525

526

527

528

529

530

531

532

533

534

535

536

537

538

539

540

541

542

543

carbono en una plantación de pino. Revista Mexicana de Ciencias Forestales 10:4-22 DOI:10.29298/rmcf.v10i51.147.

Rodríguez-Larramendi LA, Guevara-Hernández F, Reyes-Muro L, Ovando-Cruz J, Nahed-Toral J, Prado-López M, Campos Saldaña RA. 2016. Estimación de biomasa y carbono almacenado en bosques comunitarios de la región Frailesca de Chiapas, México. Revista Mexicana de Ciencias Forestales 7:77-94 DOI: 10.29298/rmcf.v7i37.53.

Rodríguez-Ortiz G, García-Aguilar JA, Leyva-López JC, Ruiz-Díaz C, Enríquez-del Valle JR, Santiago-García W. 2019. Biomasa estructural y por compartimentos en regeneración de Pinus patula en áreas con matarrasa. Madera y Bosques 25:e2511713 DOI: 10.21829/myb.2019.2511713.

Rodríguez-Ortiz G. 2010. Efecto de aclareos en el crecimiento de una plantación de Pinus patula Schl. et Cham. en Ixtlán, Oaxaca. Colegio de Postgraduados. Montecillo. Texcoco, Estado de México, México. 134 p. Available at https://nanopdf.com/download/efecto-de-aclareosen-el-crecimiento-de_pdf

Rossi S, Morin H, Deslauriers A. 2012. Causes and correlations in cambium phenology: towards an integrated framework of xylogenesis. Journal of Experimental Botany 63: 2117-2126 DOI: $10.1093 /$ jxb/err423.

Solís MR, Aguirre ÓA, Treviño EJ, Jiménez PJ, Jurado YE, Corral-Rivas J. 2006. Efecto de dos tratamientos silvícolas en la estructura de ecosistemas forestales en Durango, México. Madera y Bosques 12:49-64 DOI:10.21829/myb.2006.1221242.

Soto-Cervantes JA, López-Sánchez CA, Corral-Rivas JJ, Wehenkel C, Álvarez-González JG, Crecente-Campo F. 2016. Desarrollo de un modelo de perfil de copa para Pinus cooperi Blanco en la UMAFOR 1008, Durango, México. Revista Chapingo Serie Ciencias Forestales y del Ambiente 22:179-192 DOI: 10.5154/r.rchscfa.2015.09.040.

Thiers O, Gerdinga V, Schlatter J. 2007. Exportación de nitrógeno y calcio mediante raleo en un rodal de Eucalyptus nitens de 5 años de edad, Chile. Bosque (Valdivia) 28:256-262 DOI: 10.4067/S0717-92002007000300011.

Thomas E, Jalonen R, Loo J, Bozzano M. 2015. Cómo evitar el fracaso en la restauración forestal: la importancia de disponer de un germoplasma genéticamente diverso y adaptado a los sitios de plantación. Unasylva 66:29-36.

Vallejo VR, Smanis A, Chirino E, Fuentes D, Valdecantos A, Vilagrosa A. 2012. Perspectives in dryland restoration: approaches for climate change adaptation. New Forests 43:561-579 DOI: $10.1007 / \mathrm{s} 11056-012-9325-9$.

van Minnen JG, Strengers BJ, Eickhout B, Swart RJ, Leemans R. 2008. Quantifying the effectiveness of climate change mitigation through forest plantations and carbon sequestration with an integrated land-use model. Carbon Balance and Management 3: 3 DOI: 10.1186/1750-0680-3-3.

Vásquez-García I, Cetina-Alcalá VM, Campos-Bolaños R, Casal-Ángeles LF. 2016. Evaluación de plantaciones forestales en tres comunidades de la Mixteca Alta oaxaqueña. AgroProductividad 9:12-19.

Wang XW, Weng YH, Liu GF, Krasowski MJ, Yang CP. 2015. Variations in carbon concentration, sequestration and partitioning among Betula platyphylla provenances. Forest Ecology and Management 358:344-352 DOI: 10.1016/j.foreco.2015.08.029.

Zambrano A, Franquis F, Infante A. 2004. Emisión y captura de carbono en los suelos en ecosistemas forestales. Rev. For. Lat 35:11-20.

Zhang SY, Chauret G, Swift DE, Duchesne I. 2006. Effects of precommercial thinning on tree

Peer] reviewing PDF | (2020:02:45821:2:0:NEW 11 Jun 2020) 
544 growth and lumber quality in a jack pine stand in New Brunswick, Canada. Canadian 545 Journal of Forest Research 36: 945-952 DOI: 10.1139/x05-307.

546 Żywiec M, Muter E, Zielonka T, Delibes M, Calvo G, Fedriani JM. 2017. Long-term effect of 547 temperature and precipitation on radial growth in a threatened thermo-Mediterranean tree 548 population. Trees 31: 491-501 DOI: 10.1007/s00468-016-1472-8. 
Figure 1

Study area, showing the locations of the sampling sites used in the analysis.
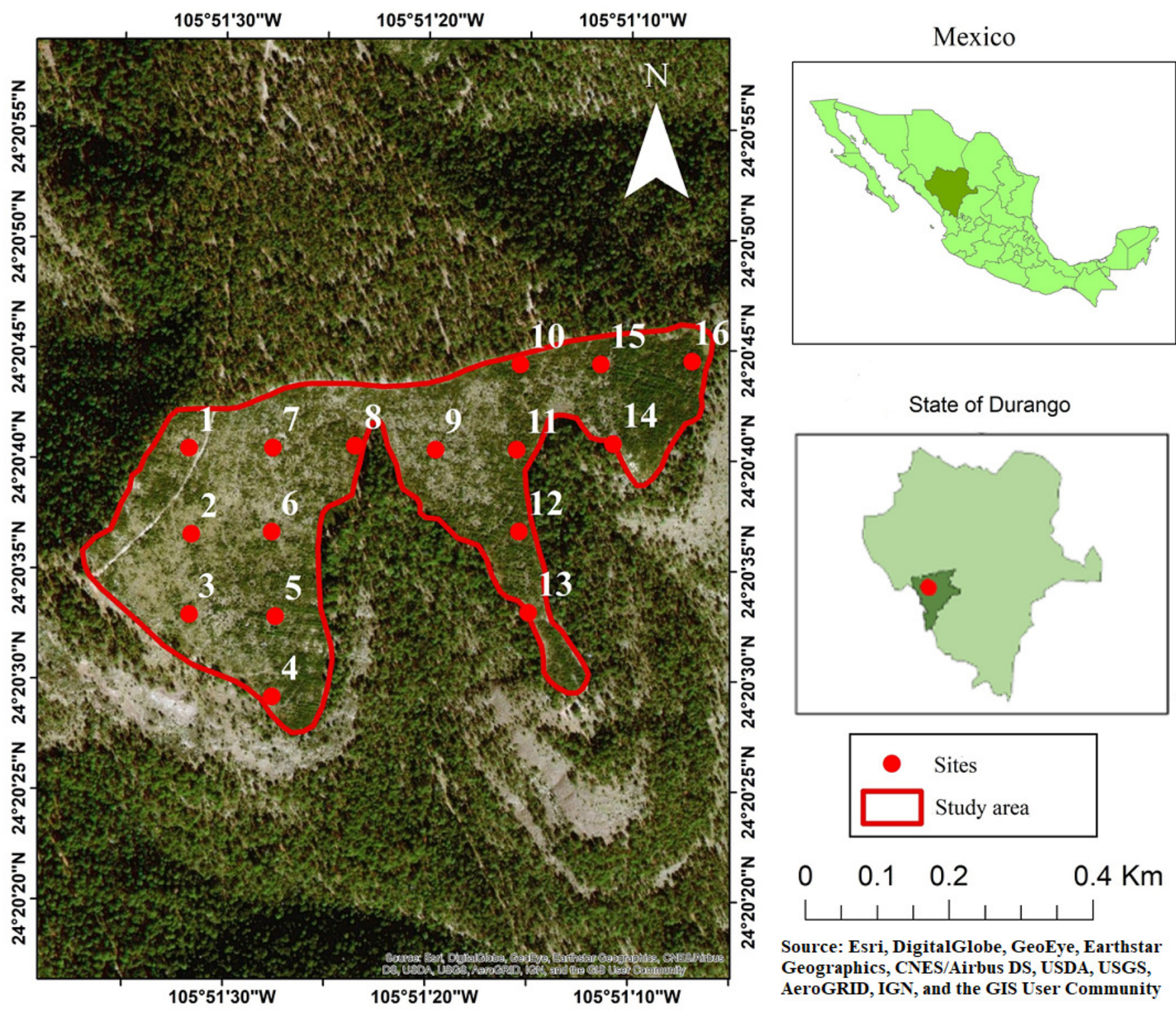
Figure 2

Average values (bars), standard deviation (lines) and groups of means according to Tukey (letters) of the ring width by species and year.

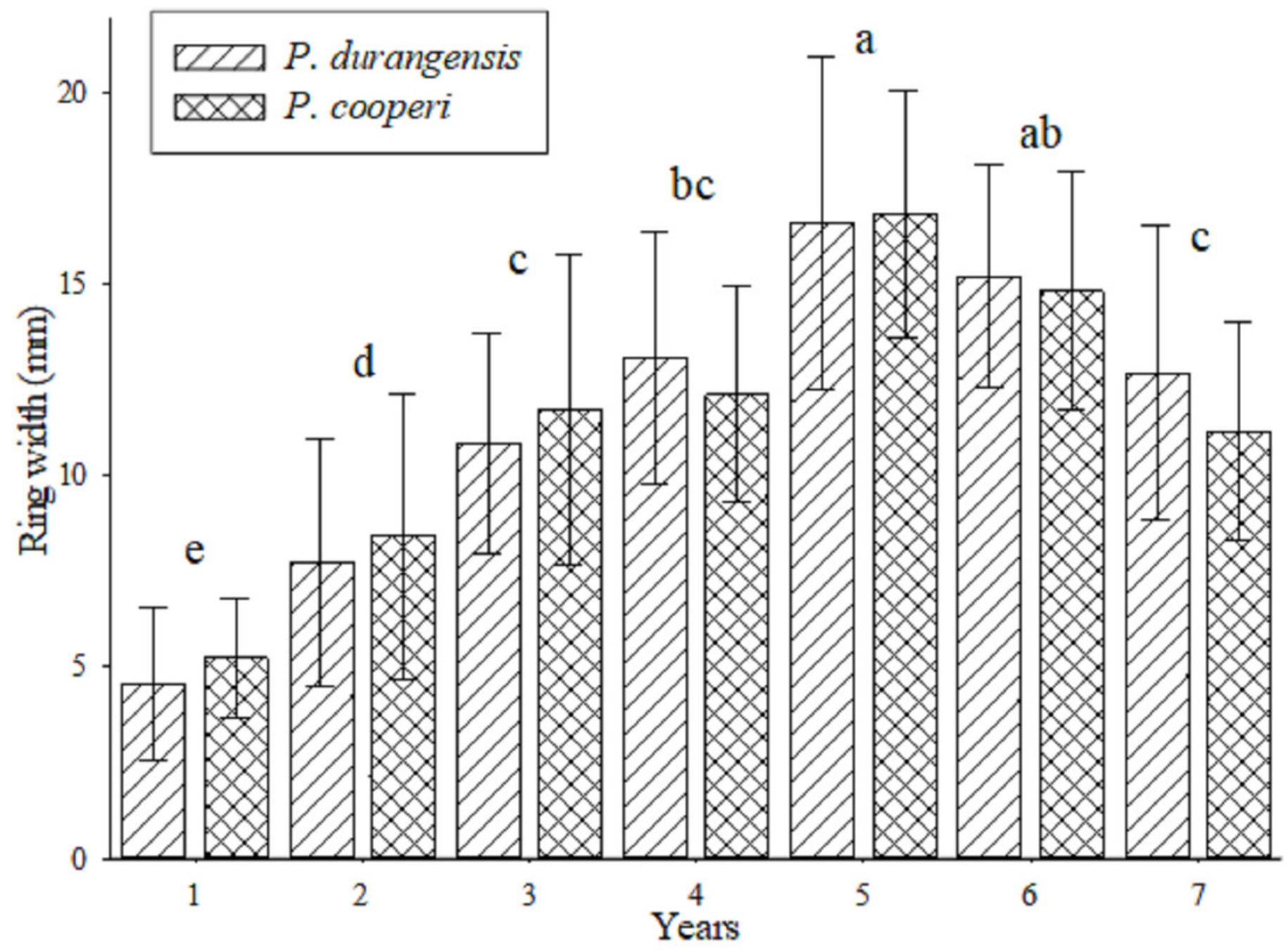


Figure 3

Average values and standard deviation of the total accumulated aerial biomass by tree of $P$. durangensis and $P$. cooperi.

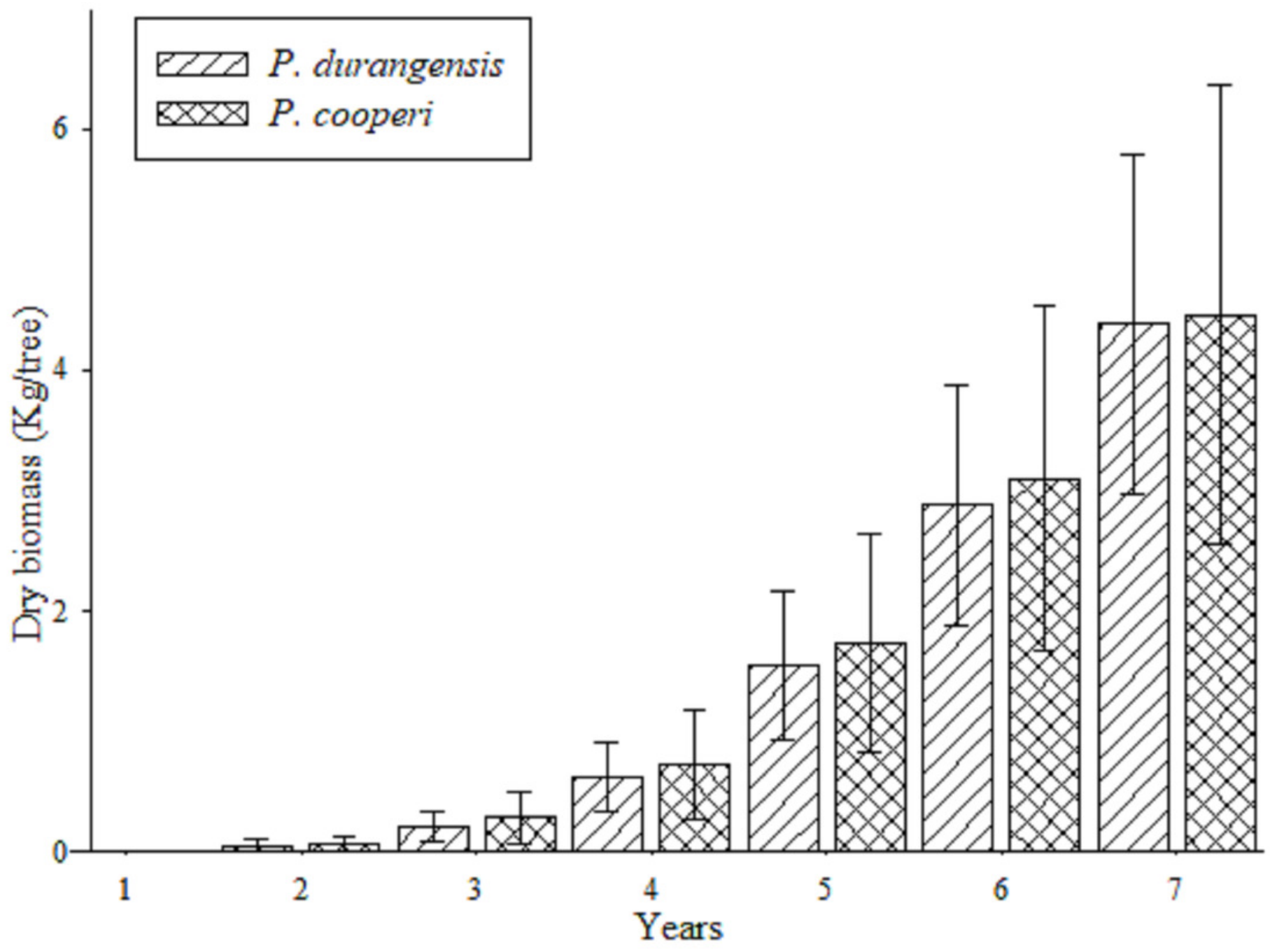




\section{Table $\mathbf{1}$ (on next page)}

Descriptive statistics for the diameter at the tree base and height of the sampled trees of Pinus durangensis and P. cooperi that were analyzed in this study (eight years old).

$\mathrm{DB}=$ basal diameter, $\mathrm{M}=$ Mean, $\operatorname{Var}=$ Variance, $\mathrm{Std}=$ Standard deviation, $\mathrm{C} . \mathrm{V} .=$ Coefficient of Variation 
1 Table 1. Descriptive statistics for the diameter at the tree base and height of the sampled trees of

2 Pinus durangensis and P. cooperi that were analyzed in this study (eight years old).

\begin{tabular}{lccccccccc}
\hline \multirow{2}{*}{ Species } & \multirow{2}{*}{ Trees } & \multicolumn{4}{c}{ DB $(\mathrm{cm})$} & \multicolumn{5}{c}{ Height $(\mathrm{m})$} \\
\cline { 3 - 11 } & & $\mathrm{M}$ & Var. & Std & C.V. & M & Var & Std & C.V. \\
\hline P. durangensis & 16 & 8.21 & 1.13 & 1.06 & 0.13 & 3.47 & 0.33 & 0.58 & 0.17 \\
P. cooperi & 16 & 8.17 & 2.24 & 1.5 & 0.18 & 3.3 & 0.67 & 0.82 & 0.25 \\
\hline D.
\end{tabular}

$3 \mathrm{DB}=$ basal diameter, $\mathrm{M}=$ Mean, Var = Variance, $\mathrm{Std}=$ Standard deviation, C.V. = Coefficient of Variation

4 


\section{Table 2 (on next page)}

Number of trees observed by site and tree species.

$\mathrm{n}=$ number of trees recorded in site $\mathrm{i}, \mathrm{N}=$ Number of trees per hectare, $\%=$ Percentage of survival. 
1 Table 2. Number of trees observed by site and tree species.

\begin{tabular}{cccccccc}
\hline \multirow{2}{*}{ Site } & $\mathrm{n}$ & $\mathrm{N}$ & $\%$ & \multicolumn{2}{c}{ Pinus durangensis } & \multicolumn{2}{c}{ P. cooperi } \\
\cline { 5 - 8 } & & & & $\mathrm{n}$ & $\%$ & $\mathrm{n}$ & $\%$ \\
\hline 1 & 19 & 1,900 & 76 & 14 & 56 & 5 & 20 \\
3 & 10 & 1,000 & 40 & 7 & 28 & 3 & 12 \\
4 & 18 & 1,800 & 72 & 11 & 44 & 7 & 28 \\
5 & 20 & 2,000 & 80 & 12 & 48 & 8 & 32 \\
6 & 15 & 1,500 & 60 & 7 & 28 & 8 & 32 \\
7 & 18 & 1,800 & 72 & 13 & 52 & 5 & 20 \\
8 & 19 & 1,900 & 76 & 13 & 52 & 6 & 24 \\
9 & 21 & 2,100 & 84 & 12 & 48 & 9 & 36 \\
10 & 20 & 2,000 & 80 & 8 & 32 & 12 & 48 \\
11 & 24 & 2,400 & 96 & 13 & 52 & 11 & 44 \\
12 & 23 & 2,300 & 92 & 16 & 64 & 7 & 28 \\
13 & 23 & 2,300 & 92 & 21 & 84 & 2 & 8 \\
14 & 18 & 1,800 & 72 & 12 & 48 & 6 & 24 \\
15 & 11 & 1,100 & 44 & 8 & 32 & 3 & 12 \\
16 & 23 & 2,300 & 92 & 18 & 72 & 5 & 20 \\
Mean & 19 & 1,900 & 76 & 15 & 60 & 4 & 16 \\
\hline
\end{tabular}

$2 \mathrm{n}=$ number of trees recorded in site $\mathrm{i}, \mathrm{N}=$ Number of trees per hectare, $\%=$ Percentage of survival. 


\section{Table 3(on next page)}

Pairwise comparisons of the estimation of year-by-year biomass and carbon content according to the Bonferroni medians comparison test.

* a significant difference at $p<0.05, * *$ a significant difference at $p<0.01$, *** a significant difference at $p<0.001$. 
1 Table 3. Pairwise comparisons of the estimation of year-by-year biomass and carbon content

2 according to the Bonferroni medians comparison test.

\begin{tabular}{|c|c|c|}
\hline Comparison (year) & Biomass & Carbon \\
\hline $1 \mathrm{vs} 2$ & 0.9507 & 0.9508 \\
\hline 1 vs 3 & $0.0013 * *$ & $0.0014 * *$ \\
\hline 2 vs 3 & 0.9816 & 0.9907 \\
\hline 1 vs 4 & $<0.0001 * * *$ & $<0.0001 * * *$ \\
\hline 2 vs 4 & $0.0034 * *$ & $0.0035 * *$ \\
\hline 3 vs 4 & 1 & 1 \\
\hline 1 vs 5 & $<0.0001 * * *$ & $<0.0001 * * *$ \\
\hline 2 vs 5 & $<0.0001 * * *$ & $<0.0001 * * *$ \\
\hline 3 vs 5 & $<0.0001 * * *$ & $<0.0001 * * *$ \\
\hline 4 vs 5 & 0.1064 & 0.1065 \\
\hline 1 vs 6 & $<0.0001 * * *$ & $<0.0001 * * *$ \\
\hline 2 vs 6 & $<0.0001 * * *$ & $<0.0001 * * *$ \\
\hline 3 vs 6 & $<0.0001 * * *$ & $<0.0001 * * *$ \\
\hline 4 vs 6 & $<0.0001 * * *$ & $<0.0001 * * *$ \\
\hline 5 vs 6 & 1 & 1 \\
\hline 1 vs 7 & $<0.0001 * * *$ & $<0.0001 * * *$ \\
\hline 2 vs 7 & $<0.0001 * * *$ & $<0.0001 * * *$ \\
\hline 3 vs 7 & $<0.0001 * * *$ & $<0.0001 * * *$ \\
\hline 4 vs 7 & $<0.0001 * * *$ & $<0.0001 * * *$ \\
\hline 5 vs 7 & 1 & 1 \\
\hline 6 vs 7 & 1 & 1 \\
\hline
\end{tabular}

$3 *$ a significant difference at $p<0.05, * *$ a significant difference at $p<0.01, * * *$ a significant difference at $p<0.001$.

4 


\section{Table 4 (on next page)}

Year-by-year biomass and carbon content for the studied pine tree species planted in a site after being harvested with a clear-cutting.

Std $=$ Standard deviation 
1 Table 4. Year-by-year biomass and carbon content for the studied pine tree species planted in a 2 site after being harvested with a clear-cutting.

\begin{tabular}{ccccccccc}
\hline \multirow{2}{*}{$\begin{array}{c}\text { Age } \\
\text { (year) }\end{array}$} & \begin{tabular}{c} 
Biomass P. durangensis \\
\cline { 2 - 9 } (kg Tree $\left.{ }^{-1}\right)$
\end{tabular} & \multicolumn{2}{c}{$\begin{array}{c}\text { Biomass } P \text {. cooperi } \\
\left(\mathrm{kg} \mathrm{Tree}^{-1}\right)\end{array}$} & \multicolumn{2}{c}{$\begin{array}{c}\text { Carbon P. durangensis } \\
\left(\mathrm{kg} \mathrm{Tree}^{-1}\right)\end{array}$} & \multicolumn{2}{c}{$\begin{array}{c}\text { Carbon P. cooperi }(\mathrm{kg} \\
\left.\text { Tree }^{-1}\right)\end{array}$} \\
\hline 1 & Mean & Std & Mean & Std & Mean & Std & Mean & Std \\
\hline 2 & 0.006 & 0.005 & 0.008 & 0.005 & 0.003 & 0.003 & 0.004 & 0.002 \\
3 & 0.047 & 0.045 & 0.060 & 0.049 & 0.024 & 0.023 & 0.030 & 0.024 \\
4 & 0.164 & 0.086 & 0.223 & 0.166 & 0.082 & 0.043 & 0.111 & 0.083 \\
5 & 0.404 & 0.183 & 0.429 & 0.250 & 0.203 & 0.092 & 0.213 & 0.124 \\
6 & 0.934 & 0.397 & 1.014 & 0.470 & 0.470 & 0.200 & 0.503 & 0.233 \\
7 & 1.324 & 0.451 & 1.366 & 0.583 & 0.667 & 0.227 & 0.678 & 0.290 \\
Total & 1.509 & 0.608 & 1.362 & 0.559 & 0.760 & 0.306 & 0.676 & 0.278 \\
\hline
\end{tabular}

$3 \quad$ Std $=$ Standard deviation 